\title{
Assessing The Impact of Empowerment on Achieving Employee Performance Mediating Role of Information Communication Technology
}

\section{Vivin Maharani EKOWATII*, Sabran ${ }^{2}$, Achmad Sani SUPRIYANTO ${ }^{3}$, Vilnanda Ulvilia PRATIWI ${ }^{4}$, Masyhuri ${ }^{5}$}

\footnotetext{
${ }^{1}$ Associate professor. Department of Management, Faculty of Economics, State Islamic University of Maulana Malik Ibrahim, Malang, Indonesia, E-mail: vivien.maharani@yahoo.com;

${ }^{2}$ Associate professor, Faculty of Eonomics and Business, Universitas Kutai Kartanegara, Tenggarong, Indonesia. E-mail: sabran@unikarta.ac.id

${ }^{3}$ Professor, Department of Management, Faculty of Economics, State Islamic University of Maulana Malik Ibrahim, Malang, Indonesia, E-mail: achmad sani72@yahoo.com;

${ }^{4}$ Research fellow in Management. Department of Management, Faculty of Economics, State Islamic University of Maulana Malik Ibrahim, Malang, Indonesia, E-mail: vilnandaulvilia@gmail.com

${ }^{5}$ Associate professor. Universitas Islam Malang, Indonesia, E-mail: masyhuri.machfudz@unisma.ac.id ${ }^{*}$ Corresponding Author
}

\author{
Received: 19.07.2021 Accepted: 20.08.2021 $\quad$ Published: 05.10.2021 DOI: 10.47750/OAS/22.184.27
}

\begin{abstract}
Human resources are seen as one of the most important assets that must be maintained, especially the existence of employees' performance, which is needed for the sustainability of organizational performance. Factors which may affect the employees' performance, are information and communication technology (ICT) and empowerment. Therefore, there is a need for human resources that are able to master technology quickly, adaptively and responsively to changing technologies. Also, it is necessary to empower employees that operate useful information and communication technology to effectively and efficiently complete their work. This study aims to determine the relationship of empowerment toward the organizational performance, to determine the role of ICT as a mediator of empowerment toward the organizational performance. A total of 200 questionnaires were distributed to employees Regional Drinking Water Company East Java Indonesia, and finally 128 questionnaires were collected and used as a sample in this study. The data were examined using smart Partial Least Squares (PLS). The results showed that empowerment has a direct effect on employee performance. In addition, information and communication technology mediated the effect of empowerment on employee performance.
\end{abstract}

Keywords: Empowerment; Employee; Performance; Information Communication Technology; PLS.

\section{Introduction}

Employee productivity is very important to support organizational performance and growth. Employee performance is a determining factor for better growth especially in service organizations (Fong and Snape, 2015, Kundu et al., 2019). Employee performance must be considered by the leader because it will increase productivity or organizational performance (Côté et al., 2020; Hasanuddin et al., 2021).

Discussing employee performance is important for the organization because if there is a problem related to employees' performance, it will affect the overall organization's performance. Therefore, organizations need to prioritize employee performance issues (Lifshitz-Assaf et al., 2019). Leaders have realized that giving employees autonomy stimulates curiosity in the work implementation. This provides opportunities for employees to try new approaches to solve problems and improve performance (Lifshitz-Assaf et al.,
2019).

Employee performance is a key factor for service organizations to gain a competitive advantage and increase productivity (Kimpah \& Ibrahim, 2020). it is necessary to empower employees to operate information and communication technology, to assist them in the effective and efficient completion of work and as an improvement of their performance (Abdul-Rasit \& Isa, 2015). Employee empowerment improves an organization's ability to enhance, develop and utilize their talents. Therefore, empowerment is considered a tool to improve employee performance (Abualoush et al., 2018). An organization with complete equipment will be useless if it cannot be operated (Idris, 2016). Empowerment practices further strengthen employees by creating ideas to increase productivity, effectiveness and organizational efficiency (Jo and Park, 2016). Consequently, the bargaining power in the workplace increases, due to the aquisition of more skills and knowledge by the employees 
(Bersin, 2015).

One way to improve public services quality is to utilize ICT (Information Communication and Technology). ICT is one of the industries that is snowballing in recent years and will continue for years to come (Kliestik et al., 2020; Farmansyah \& Isnalita, 2020). Judith \& Diveranta (2020) stated that the Indonesian community is actually adaptive to advances in ICT, although there are still gaps in its adaptiveness to technology. Consequently, there is a need for human resources that are able to master technology quickly, adaptively and responsively to technological shifts (Mulyadi, 2007). To increase efficiency and effective communication development, the business should be integrated with ICT (Yunis et al., 2017); (Asongu \& Roux, 2017), Leyer et al. (2019). Organizational performance is strongly induced by the mastery of technology from organizational members (Farmansyah \& Isnalita, 2020).

Several other studies discovered that this relationship is not significant (Tran et al., 2020) and in addition, has a moderating effect (Llopis and Foss, 2016). Saleem et al. (2019); Baird et al. (2018) stated that employee empowerment and performance are positively related. However, a study carried out by Yasotha et al. (2015); Surono and Rozak (2017) showed that employee empowerment does not affect performance. This study fulfills the gap from Surono and Rozak's (2017) by exploring and identifying causal models through ICT as mediating variables.

In a nutshell, the empowerment and employees performance in the service sector in the last decade has continued to trigger scholars' interest in this subject matter (Abualoush et al., 2018). Therefore, the main objective of this study is to overcome the contextual gap by conducting a study on employee empowerment related to employee performance. This study also expands the empirical evidence in the field of human resource management.

\section{Literature Review}

\subsection{Empowerment}

The need to empower employees is a top priority in this millennium due to the acceleration of technological development and explosion of information (Shih and Tsai, 2016; Abualoush et al., 2018). Human resource management has been changed by modern organizations following the development of managerial ideologies to gain individual loyalty and affiliation while achieving the organizational goals (Meyerson and Dewettinck, 2012). Furthermore, modern organizational managers should be interested in developing employee skills in problem-solving and decision making (Abualoush et al., 2018). An organization's ability to improve, develop and use employee talents is enhanced by its empowerment and this is considered a tool to improve them (Abualoush et al., 2018). Meanwhile, Baird et al. (2018) defined empowerment as a process to increase an individual's selfconfidence among organizational members.

Human empowerment increases the potential or ability of Human Resources. Therefore, an organization with complete equipment will be useless if it cannot be operated (Idris, 2016). Empowerment practices further strengthen employees and the workforce, they create ideas which increase productivity, effectiveness and efficiency to organize and supervise themselves (Jo and Park, 2016) and be responsible for the work they do (Nurkolis, 2003).

\subsection{Performance}

Performance is interpreted as the quality and quantity of a product or service produced (Mangkunegara, 2007) and it is the result of an individual's work in achieving the predetermined job requirements (Imron, 2018). Furthermore, it is an answer to the success or failure of an already set company goal (Kirstanti and Pangastuti, 2019). Therefore, maximizing work results is achievable by empowering employees (Surono and Rozak, 2017; Rismawati and Mattalata, 2018).

Human Resources Empowerment is a business process or activity that strengthens human potential through change and development (Idris, 2016). Employee empowerment is very important to improve the organization or work team performance and is assumed that, the expected performance will be increased by those developed with maximum empowerment. Employee performance also contributes to the improvement of an organization (Ratnasari and Hartati, 2019 Saleem et al. (2019). Baird et al. (2018) showed that employee empowerment plays an important role in improving an organization's performance.

\subsection{Information communication technology (ICT)}

Information technology is an activity that collects, process, store, distribute and also utilize information (Nuryanto, 2012) and focuses more on the results of the obtained data. Meanwhile, communication technology is more about how data is transmitted, distributed and also conveyed (Bagaskoro, 2019). All human activity in this globalization era, are assisted by technology. Therefore it is necessary to empower employees to use technology properly. Hur (2016) showed that empowerment of information and communication technology starts by increasing their interest in ICT-based activities especially with the easy and simple operations.

Leyer et al. (2019) explained that ICT ensures that empowerment is not only a concept, but sustainably empowers daily operations. Employee empowerment is expected to help them understand, adapt and operate technology in doing their work to improve their performance.

Berne et al. (2014) stated that business performance is improved by ICT and the greatest effect is on performance. Agarwal and Brem (2015) showed that the development of new capabilities through the convergence of Information Technology and Operational Technology not only change business processes, but also influences the main organizational dimensions strategy and a vision for products and markets. Based on these arguments, the proposed hypothesis includes:

$\mathrm{H} 1$ Empowerment has a direct effect on employee performance.

H2 ICT mediates the effect of empowerment on employee performance

\section{Research Methodology}

The data used to test the research model were collected from a sample of full-time employees in Regional Drinking Water Company, in East Java, Indonesia. The populations of this research are all of the employees of PT. Regional Drinking Water Company who have a minimum work period of 1 year, with 200 respondents as saturated samples. Data was collected using a questionnaire distributed to all respondents. The respondents filled out the questionnaire based on their daily work experience. Finally, a total of 128 valid responses were collected with a valid response rate of $64.0 \%$.

Empowerment indicator refers to Khan (1997) which includes: Desire, Trust, Confidence, Credibility, Accountability, and Communication. ICT indicator refers to Hur (2016) such as: 


\section{GENERAL MANAGEMENT}

Individual skills and objectives in using ICT while performance indicators refers to the opinion of Maharani et al. (2013) which includes quantity, quality, and timeliness.

The measurement scale used to measure variables is a Likert scale 1 to 5 (Sekaran, 2003). Data analysis was carried out using Smart-PLS 3.0. The criteria for measuring variables and constructs were based on the AVE value> 0.50 (Hair et al., 2014), Composite Reliability value $(C R>0.6)$ (Supriyanto et al., 2020), Cronbach's alpha $>0.5$, R-square, and loading-factor measurements as the main forming variables (Chin, 1998)

\section{Results And Discussions}

\subsection{Measurement Model}

Table 1, shows the results of the reliability testing on variables of empowerment, employee performance and information and communication technology. This shows that the Cronbach alpha value was above 0.6, therefore it was concluded that all the instruments used were reliable. Validity testing was carried out using the PLS approach with Discriminant validity by looking at the value of the AVE root (AVE). An instrument with good discriminant validity should have an AVE value above 0.5 (Solimun \& Fernandes, 2017). The results of AVE calculations are shown in Table 2.

\begin{tabular}{|l|l|l|}
\hline Variable & Cronbach's $\boldsymbol{\alpha}$ & Conclusion \\
\hline Empowerment $(\mathrm{X})$ & 0.928 & Reliable \\
\hline Employee Performance $(\mathrm{Y})$ & 0.927 & Reliable \\
\hline ICT $(\mathrm{Z})$ & 0.864 & Reliable \\
\hline
\end{tabular}

Table 1: Results of the reliability

\begin{tabular}{|l|l|l|l|}
\hline Variable & AVE & $\sqrt{\text { AVE }}$ & Conclusion \\
\hline Empowerment $(\mathrm{X})$ & 0.521 & 0.721 & Valid \\
\hline Employee Performance $(\mathrm{Y})$ & 0.733 & 0.856 & Valid \\
\hline ICT $(\mathrm{Z})$ & 0.648 & 0.804 & Valid \\
\hline
\end{tabular}

Table 2. VAVE, AVE

The composite reliability with an assumption value above 0.70 , formed constructs with good results. The results are shown in Table 3 with the value for Empowerment, Employee Performance and Information and Communication Technology variables as $0.938,0.943$ and 0.902 respectively. This means that the three analyzed variables had good composite reliability because it exceeded 0.70 , it is therefore necessary to carry out further analysis by examining the goodness-of-fit and inner model.

\begin{tabular}{|l|c|l|}
\hline Variable & Composite reliability & Conclusion \\
\hline Empowerment $(\mathrm{X})$ & 0.938 & Reliable \\
\hline Employee Performance $(\mathrm{Y})$ & 0.943 & Reliable \\
\hline ICT $(\mathrm{Z})$ & 0.902 & Reliable \\
\hline
\end{tabular}

Table 3: Results of the composite reliability

The structural model fit test used a predictive relevance score (Q2) to measure how the observed scores were generated which was based on the determination coefficient of all dependent variables between $0<Q 2<1$. The $R 2$ value of each endogenous variable was as follows: a) $\mathrm{Y} 1$ variable had $\mathrm{R} 2$ of 0.672 ; b) variable $\mathrm{Y} 2$ had $\mathrm{R} 2$ of 0.386 .

Here is a Q-square calculation:

$Q^{2}=1-\left(1-R^{1^{2}}\right)\left(1-R^{2^{2}}\right)$

$$
\begin{aligned}
& Q^{2}=1-(1-0.672)(1-0.386) \\
& Q^{2}=0.799
\end{aligned}
$$

The Q-square calculation obtained a value of 0.799 or $79.9 \%$ which means that $79.9 \%$ of the data contribution was explained by the model while other variables outside this study explained the remaining $20.1 \%$.

\begin{tabular}{|l|l|l|l|l|l|}
\hline \multicolumn{2}{|l|}{ Variable Relationships } & $\begin{array}{l}\text { Path } \\
\text { Coefficient }\end{array}$ & $\begin{array}{l}\text { t } \\
\text { statistics }\end{array}$ & p-value & Description \\
\hline Empowerment & Employee Performance & 0.436 & 4.536 & 0.000 & Significant \\
\hline Empowerment & ICT & 0.621 & 7.473 & 0.000 & Significant \\
\hline ICT & Employee Performance & 0.474 & 4.759 & 0.000 & Significant \\
\hline
\end{tabular}

Table 4: Hypothesis Testing Results for Direct Effect

The results of the direct effects described in this study are shown in Table 4 and Figure 1. Based on the empowerment effect on employee performance, a path coefficient value of 0.436 was obtained in a positive direction which means that there is a unidirectional relationship between them. Meanwhile, based on the t-statistic, a value of $4.536>1.96$ with a p-value of 0.000 was obtained. Therefore, it was concluded that empowerment directly improves employee performance. This means $\mathrm{H} 1$ is accepted. 


\section{GENERAL MANAGEMENT}

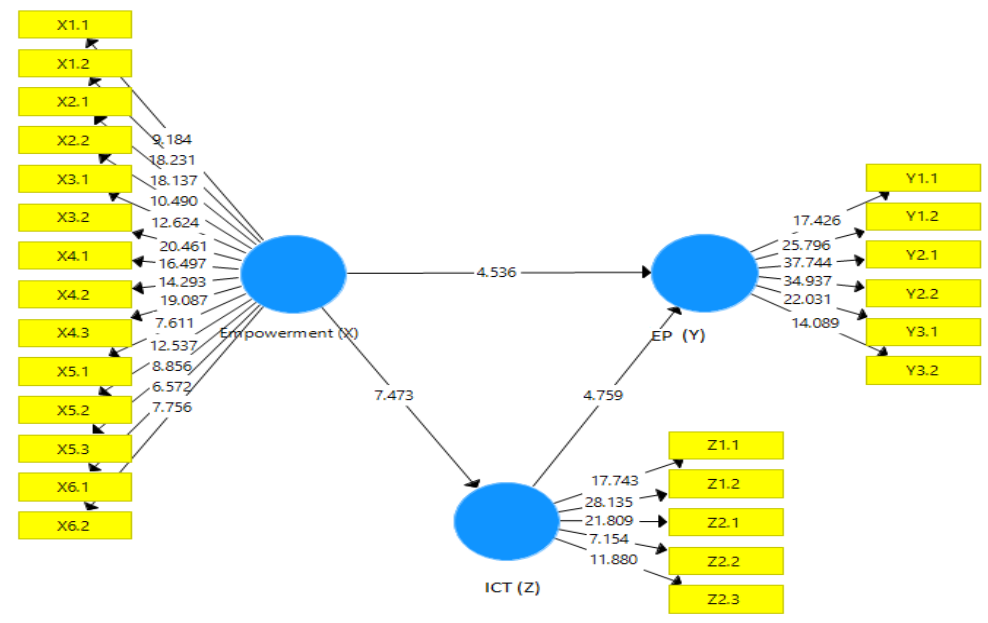

Figure 1: Path Diagram of Structural Model in PLS

\begin{tabular}{|l|l|l|l|l|}
\hline Variable Relationships & $\begin{array}{l}\text { Original } \\
\text { sample }\end{array}$ & t statistics & p-value & Description \\
\hline $\begin{array}{l}\text { Empowerment - ICT - Employee } \\
\text { Performance }\end{array}$ & 0.295 & 3.863 & 0.0000 & Significant \\
\hline
\end{tabular}

Table 5: Hypothesis Testing Results for Indirect Effects

Table 5 indicated that the mediating effect in the model was significant. This study investigates the mediating effect of ICT. For the investigation, the relationship was tested using PLS path analysis. Interestingly, ICT found to mediate the correlation between empowerment and employee performance, With the results $(\beta=0.295, p=0.000<0.000)$; therefore $\mathrm{H} 2$ is statistically accepted.

After testing the relationship between the variables, the results showed that the empowerment variable $(X)$ has a direct effect on the employee performance variable $(Y)$. This was seen from the path coefficient, the t-statistic and a $p$-value of 0.436 , $t$ statistic 4.536 and $p$ value $0.000<0.05$ respectively which means that, empowerment increases directly with the employee's performance.

Based on Table 4, the first hypothesis is accepted. This study are in accordance with the previous one conducted by Saleem (2019) which states that, the extent to which leaders allow or promote employees to participate in work is reflected by the employee empowerment. Baird et al. (2018) stated that employee empowerment delegates or involve employees to make daily decisions about work-related activities. Discoveries in the field reinforce Idris's (2016) opinion that, human resource empowerment is a business process or activity that strengthens human potentials. This is achievable through change and development in the form of ability, responsibility, trust, authority to carry out activities and organizational tasks to improve performance. Therefore, employee empowerment is very important to the performance of an organization or work team.

This study results support the opinion of Ratnasari and Hartati (2019) that the performance of an organization is improved by the contributions of their employees. The potentials to achieve superior levels of productivity and higher performance by empowered employees are because they have control over their work (Kundu et al., 2019). This also supports Supriyanto's (2019) opinion that empowerment is the extent to

affect performance. Employees exchange knowledge and information through technology which also affects performance while decision making is facilitated by the presence of which employees in a company are involved in various management activities. Furthermore, participation in management activities gives employees new knowledge, an opportunity to solve the organization's problems and become more disciplined. Empowerment is an activity that involves employees (Nurkolis, 2003) or interpreted as a business process or activity that strengthens human potentials through change and development in the form of abilities, responsibilities, trust, authority to carry out activities and organizational tasks to improve performance.

Based Table 5, the relationship between empowerment and employee performance is mediated by information and communication technology as seen from the tested using PLS path analysis. ICT mediates the correlation between empowerment and employee performance, with the results ( $\beta$ $=0.295, p=0.000<0.000)$. These results are consistent with the study by Leyer et al. (2019), that information and communication technology is very important to empower employees because it supports them to use and share knowledge actively to improve performance. Berne et al. (2014) stated that, decision-making in an organization is facilitated by the use of information and communication technology. This is in line with Abdul-Rasit \& Isa (2015), that empowerment of employees in operating information and communication technology as an improvement of their performance, is necessary to assist them in the effective and efficient completion of work. These discoveries are in line with Lee et al. (2017), Asongu \& Roux (2017), that information and communication technology is an important factor in determining the organizational performance.

Leyer et al. (2019) also stated that ICT ensures that empowerment is not only a concept, but sustainably empowers daily operations. Busro (2018) revealed that several factors, such as size of the investment or working capital, presence of technology support and good quality human resources' support information and communication technology (Nuryanto (2012). 


\section{Conclusion}

According to the results and discussion in this study, it can be concluded that empowerment has a direct effect on employee performance. Management should view it as a priority to be developed in various ways, such as delegating power to employees, increasing the understanding of the organization's value through the spread of the empowerment concept and making them participate in decision making. The effect of empowerment on employee performance is mediated by information and communication technology. Good quality human resources supported by technology affects performance because, employees exchange knowledge and information through this. The cooperation between different departments in delivering information in a timely manner to each other according to their needs, improving communication, providing

\section{References}

[1] Abdul-Rasit, Z., \& Isa, C. R. (2015). Decision facilitating role of comprehensive performance measurement system (CPMS) and job performance: Influence of role ambiguity and locus of control. Pertanika Journal of Social Sciences \& Humanities, 23(S), 145-160.

[2] Abualoush, S.H., Obeidat, A.M., Tarhini, A., Masa'deh, R. and Al-Badi, A. (2018). The role of employees' empowerment as an intermediary variable between knowledge management and information systems on employees' performance. VINE Journal of Information and Knowledge Management Systems, 48(2), 217-237. https://doi.org/10.1108/VJIKMS-08-2017-0050.

[3] Agarwal, N., \& Brem, A. (2015). Strategic business transformation through technology convergence: implications from general electric's industrial internet initiative. Int. J. Technology Management, 67(2/3/4): $196-214$.

[4] Asongu, S. A., \& Roux, S. L. (2017). Enhancing ICT for inclusive human development in Sub-Sahara Africa. Technological Forecasting \& Social Change, 118(May), 44-54.

[5] Bagaskoro. (2019). Introduction to information technology and data communication. Deepublish: Yogyakarta.

[6] Baird, K., Su, S., Munir, R. (2018). The relationship between the enabling use of controls, employee empowerment, and performance. Personnel Review, 47(1), 257-274. https://doi.org/10.1108/PR-12-2016-0324

[7] Berne, C., Garcia-Gonzalez, M., Garcia-Uceda, M. E., Mugica, J. (2014). The effect of ICT on relationship enhancement an performance in tourism channeis. Tourism Management 48 (2015), 188-189.

[8] Bersin, J. (2015). Becoming irresistible: a new model for employee engagement. Deloitte Review, 16(2), 146-163.

[9] Busro, M. (2018). Human resource management theories. Prenadamedia Group: Jakarta.

[10] Chin, W. (1998). The partial least squares approach to structural equation modeling. Modern Methods For Business Research, 295(2), 295-336.

[11] Côté, K., Lauzier, M., \& Stinglhamber, F. (2020). The relationship between presenteeism and job satisfaction: $A$ mediated moderation model using work engagement and perceived organizational support. European Management Journal. https://doi. org/10.1016/j.emj.2020.09.001

[12] Farmansyah, M.H.A., Isnalita. (2020). Information And Communication Technology in Organizational Performance of Local Government. Polish Journal Of Management Studies, 22(2), 127-141. DOI: 10.17512/pjms.2020.22.2.09

[13] Fong, K.H. and Snape, E. (2015). Empowering leadership, psychological empowerment and employee outcomes: Testing a multi-level mediating model. British Journal of Management, 26(1), 126-138. tools to develop their skills, promote initiative and give employees full freedom at work strengthens the enabling environment for empowerment.

This research certainly does not escape limitations, such as there are respondents who did not return the questionnaire. Hence, the test power was not strong enough because they were unable to get the overall data. The small sample size was insufficient to support the generalizability of the discoveries. To obtain better results, future research is recommended to increase the number of object. The effect of empowerment on employee performance mediated by information and communication technology was discussed. Subsequent studies need to consider social factors such as leadership, innovative work behavior, psychological environment and quality of worklife as antecedents of employee performance.

[14] Hair, J. F., Henseler, J., Dijkstra, T. K., \& Sarstedt, M. (2014) Common beliefs and reality about partial least squares: Comments on ronkko and evermann. Journal Organizational Research Method, 17(2), 182-209. Https://Doi. Org/10.1177/1094428114526928.

[15] Hasanuddin, B., Mustainah M and Buntuang, P.C.D. (2021) The influence of servant leadership on job satisfaction with individual vharacter as a moderating variable. Problems and Perspectives in Management, 19(1), 445-455. doi:10.21511/ppm.19(1).2021.37

[16] Hur, M. H. (2016). Empowering the elderly population through ICT-based activities: An empirical study of older adults In Korea. Information Technology \& People, 29(2), 318-333. DOI: 10.1108/ITP-03-2015-0052.

[17] Imron. (2018). Spiritual aspects of performance. UNIMA Press: Magelang.

[18] Idris, A. (2016). Introduction to human resource economics. Deepublish: Yogyakarta.

[19] Jo, S.J. and Park, S. (2016). Critical review on power in organization: Empowerment in human resource development. European Journal of Training and Development, 40(6), 390-406. https://doi.org/10.1108/EJTD-01-2016-0005

[20] Judith, M.P \& Diveranta, A. (2020). Techonology optimaly. https://kompas.id/baca/ekonomi/2020/12/01. https://kompas.id/baca/ekonomi/2020/12/01

[21] Khan, S. (1997). The key to being a leader company: Empowerment. Journal for Quality and Participation. Cincinnati, 20 (1), 44-50.

[22] Kirstanti, D. \& Pangastuti, R. L. (2019) Tips of stimulating production employee performance. Media Sahabat Cendekia: Surabaya.

[23] Kimpah, J. and Ibrahim, H. I. (2020). Participative decisionmaking, psychological empowerment and job performance: Evidence from the Malaysian electrical and electronic manufacturing firms. Pertanika J. Soc. Sci. \& Hum. 28 (2), 791802.

[24] Kliestik, T., Valaskova, K., Nica, E., Kovacova, M.and Lazaroiu, G.,(2020). Advanced methods of earnings management: monotonic trends and change-points under spotlight in the Visegrad countries. Oeconomia Copernicana, 11(2), 371-400.

[25] Kundu, S.C., Kumar, S. and Gahlawat, N. (2019). Empowering leadership and job performance: Mediating role of psychological empowerment. Management Research Review, 42(5), 605624. https://doi.org/10.1108/MRR-04-2018-0183.

[26] Lee, S.O., Hong, A., Hwang, J. (2017). ICT diffusion as a determinant of human progress. Information Technology for Development 23 (4), 687-705.

[27] Leyer, M., Richter, A. and Steinh€user, M. (2019). Power to workers' empowering shop floor workers with worker-centric digital design. International Journal of Operations and 


\section{GENERAL MANAGEMENT}

Production Management, 39(1), 24-42.

[28] Lifshitz-Assaf, H., Lebovitz, S. and Zalmanson, L. (2019). The art of balancing autonomy and control. MIT Sloan Management Review, 60(2), 1-6.

[29] Llopis, O. and Foss, N.J. (2016). Understanding the climate knowledge sharing relation: The moderating roles of intrinsic motivation and job autonomy. European Management Journal, 34(2), 135-144.

[30] Maharani, V E., Troena, E.A., Noermijati, N. (2013). Organizational citizenship behavior role in mediating the effect of transformational leadership, job satisfaction on employee performance: Studies in PT Bank Syariah Mandiri Malang East Java. International Journal of Business and Management, 17, 112.

[31] Mangkunegara, A.P. (2007). Human resource performance evaluation. PT. Revika Aditama: Bandung.

[32] Meyerson, G. and Dewettinck, B. (2012). Effect of empowerment on employees performance. Advanced Research in Economic and Management Sciences (AREMS), 12(2), 4046.

[33] Mulyadi. (2007). Management planning and control system. Salemba Empat: Jakarta.

[34] Nurkolis. (2003). School based management: Theory, models, applications. Grasindo: Jakarta.

[35] Nuryanto, H. (2012). History of the development of information, and communication technology. PT Balai Pustaka: Jakarta.

[36] Ratnasari, S.L. \& Hartati, Y. (2019) Performance management in organizations. Qiara Media: Pasuruan.

[37] Rismawati \& Mattalata. (2018) Performance Evaluation: Performance appraisal on the basis of future oriented work performance. Celebes Media Perkasa: Makasar.

[38] Saleem, M. A., Bhutta, Z., M., Nauman, M., Zahra, S. (2019). Enhancing Performance And Commitment Through Leadership And Empowerment An Emerging Economy Perspective. International Journal of Bank Marketing 37(1), 303-322 .
[39] Sekaran, U. (2003). Research method for business: A skill building approach. New York: John Wiley and Sons, Inc.

[40] Shih, W.L. and Tsai, C.Y. (2016). The effects of knowledge management capabilities on perceived school effectiveness in career and technical education. Journal of Knowledge Management, 20(6), 1373-1392

[41] Solimun, \& Fernandes, A. A. R. (2017). Investigate the instrument validity consistency between criterion validity and unidimensional validity (case study in management research. International Journal of Law and Management, 59(6), 1-10. https://doi.org/10.1108/IJLMA-09-2016-0076.

[42] Supriyanto, A. S. (2019). Obtaining factors affecting innovative work behavior (IWB) of a local bank employees under islamic leadership: Application of partial least squares method. Industrial Engineering \& Management System, 18(3), 417-425.

[43] Supriyanto, A.S., Ekowati, V.M. Haris, A., Soetjipto, B.E., Harianto, R., Yahya, M. (2020). The effect of organizational citizenship behavior on job satisfaction mediated with spiritual leadership. International Journal Of Business And Society, 21(2), 737-748.

[44] Surono., Rozak, H. A. (2017). The Influence of Empowerment and Compensation to Performance. Jurnal IImiah Telaah Manajemen, 14(1), 127-137.

[45] Tran, L.T.T., Thi Vinh Hien, H. and Baker, J. (2020). When supportive workplaces positively help work performance. Baltic Journal of Management, Vol. ahead-of-print No. ahead-of-print. https://doi.org/10.1108/BJM-06-2020-0220

[46] Yasothai, R., Jauhar, J., Bashawir, A. G. (2015). A study on the impact of empowerment on employee performance: The mediating role of appraisal. International Journal of Liberal Arts and Social Science, 3(1), 92-104.

[47] Yunis, M., El-Kassar, A.-N., \& Tarhini, A. (2017). Impact of ICTbased innovations on organizational performance. Journal of Enterprise Information Management, 30(1), 122-141. doi:10.1108/jeim-01-2016-0040 